小児脳神経外科領域での周術期管理

坂本 博昭 ${ }^{1)}$, 松阪 康弘 ${ }^{1)}$

1）大阪市立総合医療センター小児医療センター小児脳神経外科

\title{
Perioperative Management in Pediatric Neurosurgery
}

\author{
Hiroaki Sakamoto, M.D. ${ }^{1)}$, and Yasuhiro Matsusaka, M.D. ${ }^{1)}$ \\ 1) Department of Pediatric Neurosurgery, Children's Medical Center, Osaka City General Hospital
}

Pediatric neurosurgeons deal with various pathologies of neurosurgical diseases, such as anomalies, hydrocephalus/cerebrospinal fluid disorders, tumors, vascular diseases and head injuries, and also with patients who range wildely in age from fetus to young adult. In the present review we describe the principles of perioperative management in pediatric neurosurgery, focusing on fetuses, neonates and infants and typical diseases in the field of pediatric neurosurgery, in addition to informed consent for children.

(Received November 9, 2012 ; accepted November 12, 2012)

Key words : pediatric neurosurgery, perioperative management, informed consent, cranio-cerebral disproportion Jpn J Neurosurg（Tokyo）22:269-275, 2013

\section{はじめに}

小児脳神経外科領域での周術期管理で成人と大きく異 なるのは, 胎児期に診断される例や新生児期や乳児期の 例であり，小児期に特徵的な疾患としては中枢神経系の 先天性疾患，水頭症などの髄液の異常に関連する疾患， 小児脳腫瘍，もやもや病，虐待に伴う頭部外傷などがあ る.また,インフォームド・コンセント informed consent の考え方も小児特有といえる，本項では，このような小 児に特有な項目と代表的な疾患を挙げ，小児脳神経外科 領域の周術期管理について解説する.

\section{インフォームド・コンセント}

法的拘束力のあるインフォームド・コンセントには, 医療者からの疾患に関する偏りのない適切な情報の提 供, 患者による疾患情報の理解, 患者の自由意思による
自己決定，という 3 つの要素が必要とされる。览脳神 経外科領域では各疾患の症例数が限られているため, 䀢 学的な高いエビデンスレベルの情報が少なく, 標準的と いうべき治療法が推奨されている疾患は少ない。そのた め，たとえば無症候性の脊髄脂肪腫に対し予防的係留解 除を積極的に勧める医師や施設が多いが，予防的治療が 自然歷よりもよい結果を生むという明確なエビデンスは まだないため, 慎重な経過観察という選択肢を患者側に 提示したうえで，方針を決定していく必要がある。小児 ではまた, 患児に代わって親権者が方針を決定するので, 方針の決定に親権者が悩めば，疑問に答え不安な気持ち を傾聴して現状を受け入れるように促し，満足できる決 定ができるように支援すべきである，時間的な余裕があ ればセカンドオピニオンを受ける提案を行う.

もし親権者が標準的な治療を選択しない場合は，まず その理由として提供した情報を十分に理解しているかど うかを確認する必要がある。理解したうえで標準的な治

連絡先：坂本博昭， $\overline{\mathbf{T}} 534-0021$ 大阪市都島区都島本通 2-13-22 大阪市立総合医療センター小児医療センター小児脳神経外科 Address reprint requests to: Hiroaki Sakamoto, M.D., Department of Pediatric Neurosurgery, Children's Medical Center, Osaka City General Hospital, 2-13-22 Miyakojima-hondori, Miyakojima-ku, Osaka-shi, Osaka 534-0021, Japan 


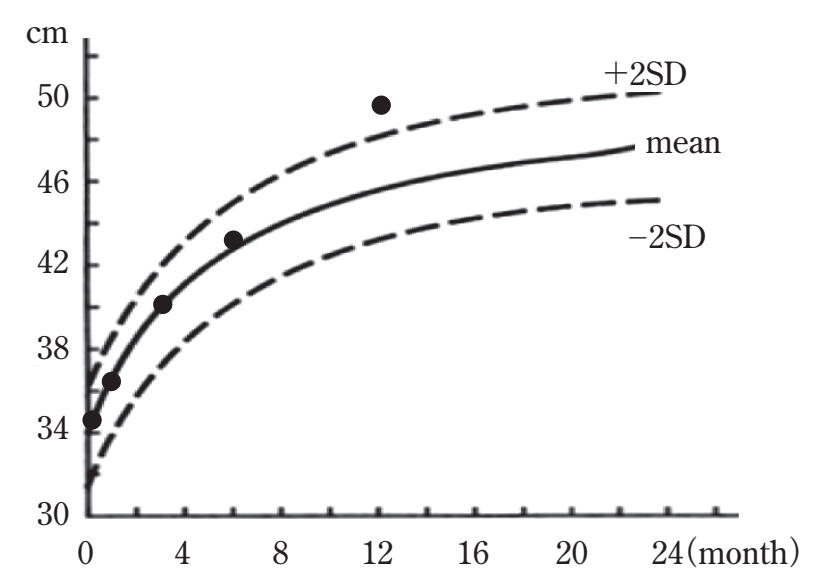

Fig. 1 Head circumference chart for girls

Head circumference (HC) in boys is $1 \mathrm{~cm}$ larger than that in girls. In this baby with hydrocephalus, $\mathrm{HC}$ stayed around the mean of $\mathrm{HC}$ at birth and at 3 months of age and was increased to just over the mean at the age of 6 months, followed by a rapid increase over the upper limit of $+2 \mathrm{SD}$ at the age of one year. Such an abnormal increase in $\mathrm{HC}$ may indicate that the onset of hydrocephalus occurred around the age of 6 months.

療を受けないという選択肢を取る場合，医療者は患児の 利益になるようにその理由を確認するなど親権者に働き かけを行い，再考を促す。また，標準的な治療法が提唱 されていないため種々の方針が選択可能な場合でも，医 学的にみて明らかに患児に不利な方針の決定がなされる 場合も親権者に再考を促す。たとえば，悪性脳腫瘍の終 末期で，担当医師の提案に反し，わずかな延命効果を期 待して親権者が患児に過大な負担を強いる治療や死期を 早める可能性の高い治療を希望する場合，小児緩和医療 の専門医など関連する医療者を交え，親権者の思いや年 長者であれば患児の意思を聴取して方針について検討す る。必要な医療行為に保護者が同意しない小児の医療ネ グレクトの場合, 法律が改正されたので, 法的に親権を 一時停止して治療を受けさせることが容易となった。

7 歳以上の例では年齢に合わせた情報を提供し，それ を理解したうえで治療の了解を患児から得るインフォー ムド・アセント informed assent（法的拘束力はない）の 手続きを踏むようにする ${ }^{4)}$.

\section{周術期の評価}

生後 1 カ月までを新生児，1歳までを乳児とし，1６ 歳までを幼児とする，新生児は出生体重によって，低出 生体重児 low birth weight infant（出生時体重 2,500 g 未 満), 極低出生体重児 very low birth weight infant（同
1,500 g 未満), 超低出生体重児 extremely low birth weight infant（同 $1,000 \mathrm{~g}$ 未満）に分類される。また在胎 (妊娠) 週数によって，正期産児 term infant（在胎 37 週 以上 42 週未満), 早産児 preterm infant (在胎 37 週未満) などに分類され，未熟児という曖昧な表現はしなくなっ た.

\section{1 理学的所見}

\section{1. 全身状態}

バイタルサインの中で, 健常児の体温は $36.5 \sim 37.5^{\circ} \mathrm{C}$ で，口腔や直腸での深部体温は腋窩温よりも $0.5 \sim 1.0^{\circ} \mathrm{C}$ 高く，深部体温が $35.5^{\circ} \mathrm{C}$ 以下を低体温という。新生児期 や乳児期では異常に低下，上昇すれば意識障害や痤攣を きたすので，保育器内での管理，頭部の保温や室温の調 整など体温の維持を心がける，小児例でも頭蓋内圧方進 に伴って Cushing 現象が発生する。新生児では脈拍数 150 200 回/分が正常で, 入眠時には 100 回/分以下にな ることがある。呼吸回数は $40 \sim 60$ 回/分が正常で，在胎 33〜34 週までに出生した低出生体重児では病的原因が なくても 15〜20 秒間の呼吸停止やチアノーゼを伴う無 呼吸発作がある。生後 1 力月以降の乳児では, 脈拍 80 160 回/分, 血圧 $80 \sim 100 \mathrm{mmHg}$, 呼吸回数 $30 \sim 40$ 回/分 が正常である. 幼児では心拍数は 90〜110 回/分, 血圧は 90〜 $120 \mathrm{mmHg}$ が正常である.

外表所見では頭部では大泉門を触診し, 頭囲 head circumference は頭部の最大周径で, 通常前頭結節と外後頭 隆起を通過するように測定する。頭囲曲線上から頭蓋の 成長を評価する (Fig. 1)。神経外胚葉由来の神経板の左 右端が背側正中部で癒合して神経管がつくられ，これか ら脳・䐏髄が形成される。神経管閉鎖不全（二分頭蓋や 二分脊椎）を示唆する皮膚病変を正中部（鼻，鼻根部， 前額部, 前頭部, 後頭部, 後頝部, 背部, 腰部, 腰仙部) に認めれば, 神経病変と頭蓋骨や春椎の病変の関連性を 画像上で検討し，治療時期や方法を決定する.

\section{2. 神経学的所見}

意識状態の評価法として，小児でも成人に準じて Japan Coma Scale や Glasgow Coma Scale が使用される. 乳幼児期の頭蓋内圧六進による症状として繰り返す噴水 様嘔吐がある。頭部を拳上した体位では大泉門部は平坦 か軽度佇凹し，啼泣や頭蓋内圧元進により緊張や膨隆を きたす. 大泉門は慢性の頭蓋内圧方進があれば生後 1 歳 6 力月を過ぎても閉鎖しないが，鎖骨頭蓋異骨症，ダウ ン症でも閉鎖が遅れる。頭囲曲線からは頭蓋内圧六進の 有無や発症時期が推定できる (Fig. 1)。成人と同様に頭 蓋内圧立進により外転神経麻痺をきたすことがある. 

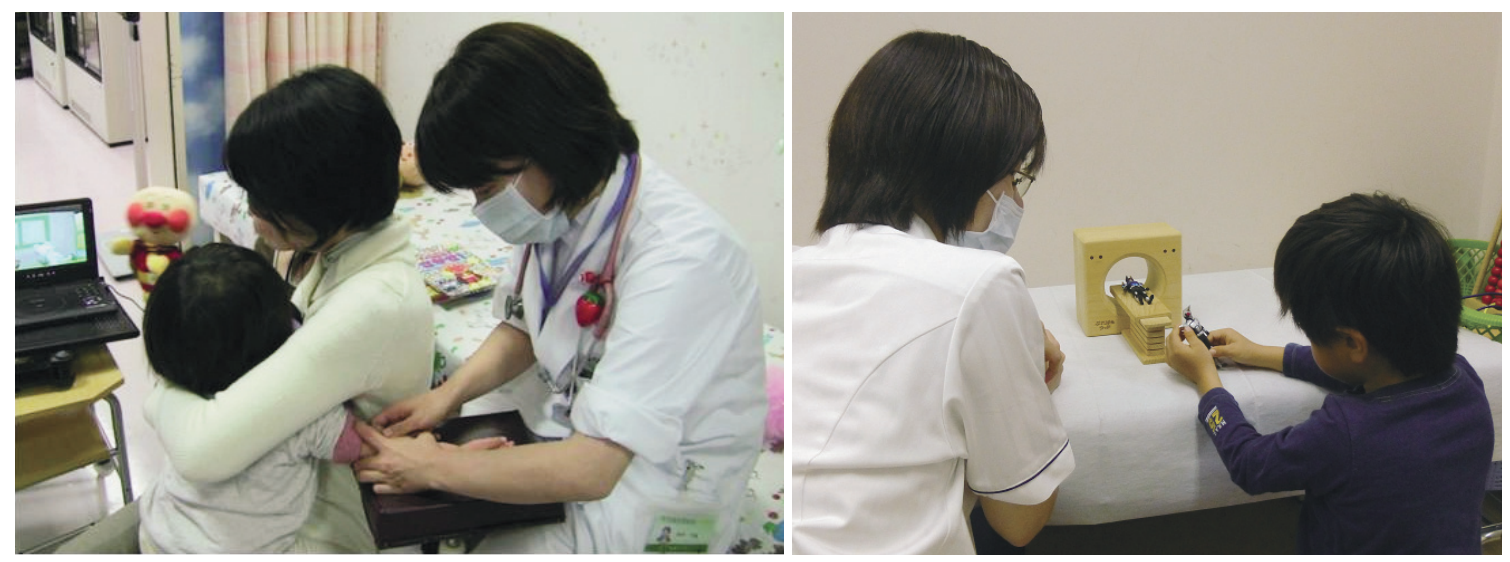

Fig. 2 Distraction and preparation techniques for children in medical practices

Left: Distraction technique. A child is tightly held by her mother while her attention is distracted by her favorite video and stuffed toy, as blood is taken from the right arm.

Right: A wooden model of CT equipment used to prepare children for their radiology procedures.

2,3 歳までの年少児期では片麻痺や小脳症状など脳の 局所症状を運動発達遅滞と判断しないようにする。四肢 の随意運動を観察して麻痺の有無を評価し，後頭蓋窩腫 瘍では片足立ち，つぎ足歩行などにより小脳症状を検索 する。いったん獲得した能力を失う退行現象がないかど うかを病歴から判断する。

標準的な発達の指標を示すと, 在胎 32 週を過ぎれば 自発的な覚醒がみられ，明るいと眼を閉じ，対光反射は 在胎 35 週までには認める. 在胎 28 週で探索反射がみら れ，34 週より鰃下運動を認める。聴覚では在胎 28 週で も大きな音には反応する。新生児期には指の把握反射, Moro 反射, 非対称性緊張性顤反射がみられる. $3 \sim 4$ 力月 児では定䅡がみられ，あやすと笑い追視する，7 カ月ま でには寝返りができ，手で支えずに座位が取れる。個人 差が大きいが，10 カ月で四つ這いが可能となり，つかま り立ち，母指と示指の腹でつかむことが可能となり，バ イバイの動作ができる。1 歳児ではつたい歩きから独り 立ちができ，1歳半には歩き回り，パパ，ママなどが言 え, 名前を呼ぶと振り向く.2 歳では安定した歩行で走 れるが, wide based gait は異常である。 3 歳では片足立 ちは 2,3 秒間可能で，階段を交互に足を出して昇り， 二語文が出る。これ以降は成人に準じて神経学的所見を 得る。

\section{2 補助検査}

疼痛を伴わない CT，MRI や脳波検査でも，6歳まで の多くの小児例では安静が保てないため鎮静処置が必要 となる。眠剤として，トリクロホスナトリウムの経口投 与 $(0.2 \sim 0.8 \mathrm{ml} / \mathrm{kg}$, 鎮静効果が不十分なときは初回の 1 /
2 の量を追加し，全量で $20 \mathrm{ml}$ 以下とする）もしくは座 薬として抱水クロラール（エスクレ座薬 ${ }^{\circledR} ）(30 \sim 50 \mathrm{mg} /$ $\mathrm{kg}$ ，投与前に浣腸して排便させておく）がしばしば用い られるが，ポルフィリン症には禁忌である。ペントバル ビタールの注腸（20～ $40 \mathrm{mg} / \mathrm{kg} ， 10 \%$ 溶液で投与）は喘 息，ポルフィリン症には禁忌であるが，上記の方法が有 効でない場合に用いられる。呼吸や全身の状態が悪い例 では，血管確保， $\mathrm{SaO}_{2}$ モニター装着などペントバルビ タールやミダゾラムなどの静脈内投与による鎮静処置に 準じて呼吸管理ができるように準備し,慎重に監視する.

最近，幼児でもできるだけ薬物を使用しないで，検査 や処置を受けられるような試みがある。Distractionの手 法では，患児の気に入ったおもちゃで遊ばせたり，興味 を引く画像を見せることによって，処置や検査による苦 痛や不安から気をそらす（Fig. 2)。また，検査や処置の 前に，検査や処置の絵や写真を見せたり検査の模型を用 いて説明し，心の準備を促す preparation という手法があ る（Fig. 2)。これには医師，看護師のみならず，病院保 育士もしくは専門的な教育を受けて資格をもつホスピ夕 ル・プレイ・スペシャリスト hospital play specialist（イ ギリスでの名称で，アメリカではチャイルド・ライフ・ スペシャリスト child life specialist と呼ばれる)が担当す るようになった。

MRA や 3D-CT による画像情報がよくなったため, 当 院では侵襲的な脳血管撮影は，血管に富む腫瘍（術前に 栄養血管の塞栓術の検討が必要な例), 血管性病変以外で 診断を目的に行われることはほとんどなく22，髄芽腫， 上衣腫，頭蓋咽頭腫などの腫瘍では通常血管撮影は行っ ていない，放射線被曝を少なくするために，CT では眼 

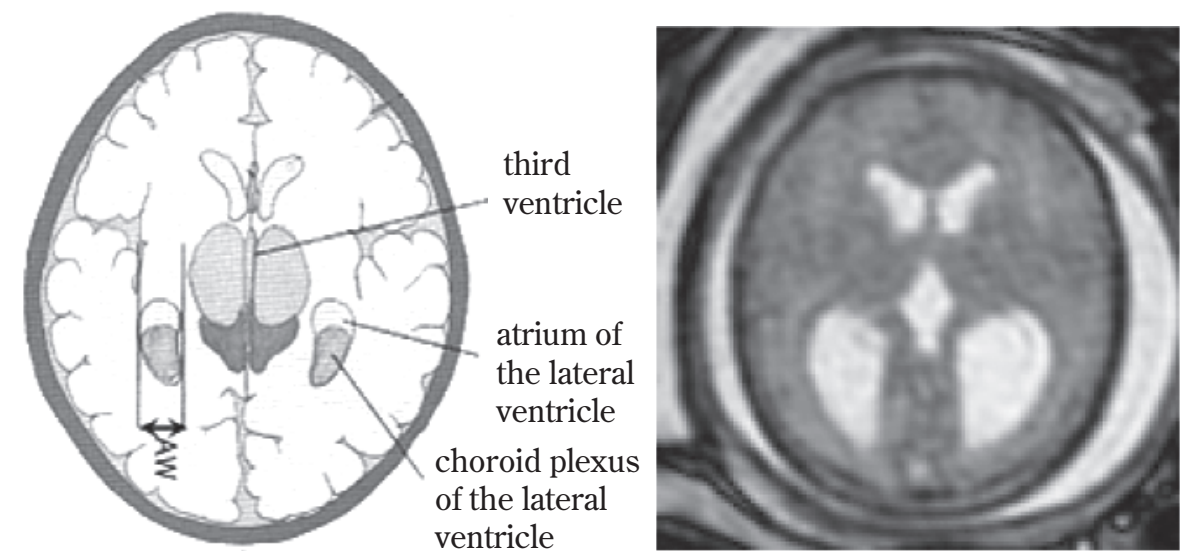

Fig. 3 Atrial width of the lateral ventricle in a fetus

Left: Schematic drawing of the atrial width of the lateral ventricle (Created based on the figure of ref. 8).

Right: Fetal MRI on the gestational age of 32 weeks showing an atrial width of $20 \mathrm{~mm}$ in a fetus with myelomeningocele.

球を外したスライス面で撮像する方法がとられる.

\section{周術期の管理}

\section{1 特殊な年齢層}

\section{1. 胎児期}

産科医による胎児のスクリーニング超音波エコー検査 で病変が疑われれば, 胎児の MRIが行われる。胎児期水 頭症の約 $1 / 3$ が脊髄髄膜瘤で, 最も多い疾患である. 胎 児期では妊娠週数にかかわらず atrial width が $10 \mathrm{~mm}$ 以 上を脳室拡大と判定する $(\text { Fig. } 3)^{8)}$. 脳室拡大がすべて 水頭症とはいえず，健常児でも軽度の拡大を呈すること があり，脳形成不全に伴った脳室拡大の例もある。

脳神経外科疾患の家族への説明は最も豊富な知識や経 験をもつ脳神経外科医が行う。通常は胎児の画像情報の みから診断，治療予測，予後判定を行うため，出生前診 断である程度の予後判定が可能な脊髄髄膜瘤を除いて, 多くの例では診断や予後評価は不確実であることを親に 認識してもらう必要がある。このように画像所見が典型 的でなければ, 出生後もしくは出生後経過をみて診断や 治療方針を立てることになる。

胎児の疾患が診断されるもしくは疾患の疑いをもたれ た場合，親には疾患の情報提供のみならず，産科医を中 心とした周産期医療に携わる医療者が心理的，精神的な 支援を行う。日本では人工妊娠中絶が認められていない 妊娠 22 週以後(妊娠 21 週 6 日以降) に診断された場合, わが子を受け容れ育てていけるよう医療者が支援してい く姿勢を示す。親は期待に反して病気をもった（もって
いるかもしれない) わが子を育てていくという将来への 不安，そして自分たちの子に限ってなぜ病気をもって生 まれてくるかという現状への不満をもつ。説明にあたつ てはこのような不安や不満から出ることばを傾聴し，そ のうえで日常生活の問題など現実的な情報のみならず, 同様な疾患をもつた家族が満足した生活を過ごしている 例を挙げるなど，少しでも希望をもたせるように心がけ る。著者らは親の気持ちを考慮し，医学用語として一般 的に使用されている奇形，異常などの用語は病気，変化 などと言い換えている。

病気の子を産む（産んだ）という母親へは周囲からの 医学的根拠のない偏見が起こりやすいので, これから母 子を守るょうに他の家族にも説明する。ささらに，出生後 は児の世話にあたる親（通常は母親）に身体的，精神的 な負担がかかる。適切な相談相手が周囲になく親子が孤 立すれば，子どもへの虐待や家庭崩壊へと向かうため， 周りの家族のみならず訪問看護や経済的な支援など地域 社会が支えるシステムがあることを知ってもらう。

\section{2. 新生児期から乳児期}

早産児や低出生体重児では, 肺や脳の未成熟性に伴っ て新生児呼吸促迫症候群 idiopathic respiratory distress syndrome（IRDS）や新生児脳室内出血が問題となる. IRDS は在胎 32 週未満, 出生体重 $1,500 \mathrm{~g}$ 未満の児に多 く，新生児科（小児科）による厳重な呼吸管理が必要と なるため, 出生後の早期に全身麻酔による外科治療が行 えないことがある。新生児脳室内出血は在胎週数が 34 週未満で発生しやすく，重症であ玌ば合併する水頭症に 対し外科的な髄液排除が必要となる。脳室腹腔シャント 

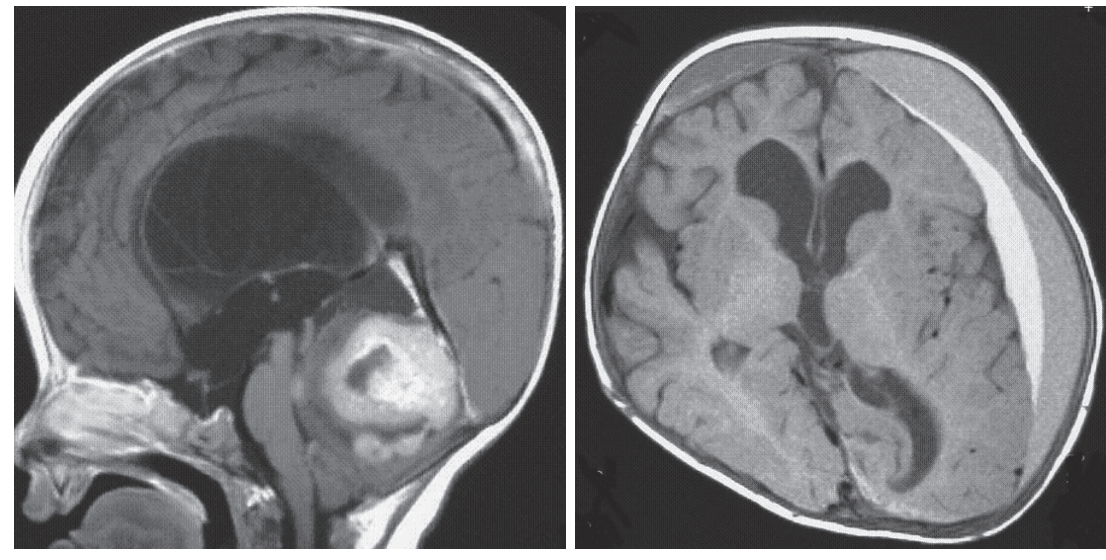

Fig. 4 An infant with craniocerebral disproportion

Left: This infant has an enlarged skull due to non-communicating hydrocephalus caused by a posterior fossa tumor.

Right: Although the lateral ventricles decreased in size after total removal of the tumor, multiple layered subdural hematomas are observed in both hemispheres as a result of the craniocerebral disproportion.

が技術的に困難な低体重出生児や早期産児など体重が $2,000 \mathrm{~g}$ 以下の新生児では頭皮下にオンマヤリザバーを 設置し，このリザバーを間欠的に穿刺して脳室内の髄液 排除を行う。䯣膜炎に注意しながら, 体重が $2,000 \mathrm{~g}$ (で きれば $2,500 \mathrm{~g}$ ）に増えるまで待ってシャントを行う ${ }^{8)}$.

\section{2 代表的な疾患}

\section{1. 脊髄髄膜瘤}

出生後の管理として, 腹臥位として尿や便による污染 を避け, 外表に露出した神経組織を保護するためにガー ゼで保護し，この状態を修復後まで維持する（この体位 は脊䯣脂肪腫の術後にも用いる). 全身の合併疾患の検索 を行い, 修復は生後 48 時間以内 (遅くとも 72 時間以内) に行うと細菌感染は起こりにくい7). 合併する水頭症に 対し, 修復時にシャント手術やオンマヤリザバーの設置 を行うとする意見があるが，著者の施設では少しでも細 菌感染の危険性を減らすために修復した数日後にシャン トを行っている。シャント術後に腹部膨満など麻痺性イ レウス症状がみられれば，髄液検査で細菌感染の可能性 を否定し, 絶食にして改善を待つ. シャント閉塞は 1 歳 までに高率に発生しやすい. キアリII 型奇形は画像上で 90\%の例に認められるが，症候性（嚥下障害，喘鳴，無 呼吸，チアノーゼ，後弓反張など）となるのは $10 \%$ 程度 と頻度は多くない。このような症状はシャント閉塞に よっても発生するため，まずシャント機能を確認する. 症状が進行性の場合は大孔部や上位頝髄部の減圧が必要 となるが，重症例では治療効果は期待しにくい.

\section{2. 水頭症}

腫瘍などによる非交通性の水頭症では原因治療が原則 であるが，1歳未満の例では内視鏡的な第 3 脳室開空の 有効性は低い3)，小児では原因となる疾患が明らかでな い例が多く，脳室腹腔シャントが主流である。シャント は人工物を埋め込む手術という認識をし, 術後のシャン 卜感染やシャント閉塞の症状を見落とさないようにす る。術後は創部の管理が重要で，乳児ではシャント周囲 の皮下の髄液貯留は髄膜炎を合併しやすい，疑わしけれ ば髄液検査を行って，髄膜炎と判断すれば速やかにシャ ントをすべて抜去し, 新たに脳室ドレナージを設置する。 新生児期や乳児期で頭蓋内圧立進が慢性に継続し, 縫 合が離開して頭蓋が大きくなれば craniocerebral disproportion に陥りやすい. 水頭症など頭蓋内圧立進により脳 室拡大と異常に拡大した頭蓋を呈した例では，頭蓋内圧 六進の原因となる病態が改善されても，脳容積はすぐに は増大せず， craniocerebral disproportion の状態となり， 大きな頭蓋と脳表面との間の硬膜下腔に液の貯留や血腫 が発生する（Fig. 4)，頭蓋がすでに異常に大きくなった 水頭症に対するシャント治療では，overdrainage を防ぐ ようなシャントシステムを選択し，また術後に頭部を挙 上する体位を避けるようにする。

また，1歳を過ぎ立位の時間が長くなれば，慢性的な overdrainage によって脳室が slit 状に狭小化し，シャン トが閉塞しても脳室が拡大しにくく，急速な頭蓋内圧立 進による意識障害の進行をきたしやすい6)．年長児で シャント閉塞が疑われる症状があれば，画像上でわずか な脳室の拡大もシャント閉塞と考えてシャント造影など 
の精査を行う。

\section{3. 頭蓋骨縫合早期癒合症}

症候群性の例は非症候群性の例よりも重症で, 頭蓋の 狭小化が強く，上顎骨の低形成による上気道狭窄による 呼吸障害が発生しやすく, 水頭症や小脳扁桃の下垂など 脳病変を伴いやすい．年少児での頭蓋形成術では輸血の 準備は必須である。

\section{4. 脳腫瘍}

乳児期で生命予後にかかわるような術中の問題とし て, 静脈洞やガレン大静脈の直接損傷やこれに流れ込む 大きな橋静脈の損傷, 主幹動脈の損傷, 術中の静脈洞の 急性閉塞，もしくは主要血管の損傷による脳深部への出 血の流れ込みによる急性の頭蓋内圧六進がある. 術前に はこのような血管構築に関する画像評価が重要である。

下垂体から視床下部に発生する頭蓋咽頭腫，肧細胞系 腫瘍，視神経・視床下部神経膠腫，ラトケ囊胞では，術 前に内分泌系の検索を十分に行う。汎下垂体機能不全の 状態で副腎皮質ホルモンのみを補充すると尿崩症が顕在 化することがある，尿崩症の診断基準に合えば，抗利尿 ホルモンの補充を行うが，水中毒による意識障害や痓攣 に注意が必要である。

小児では脈絡叢乳頭腫，髄芽腫，上衣腫なぞ脳室内や その周囲に腫瘍が発生すれば，水頭症の症状で発症する 例が多い，意識障害を呈したり，症状が急速に悪化する 場合を除いて，ステロイドや浸透圧利尿剂を投与すれば 頭蓋内圧元進症状が改善し, 術前の必要な画像検査を 行って腫瘍の摘出を行えば水頭症が改善することが多 い. 水頭症に対するこのような薬物治療が無効で, 腫瘍 の摘出が緊急で行えない場合には脳室ドレナージやシャ ントで水頭症状態を改善することになる。後頭蓋窩の腫 瘍では天幕上の減圧によって，上方性のへルニアが発生 し意識障害，呼吸障害をきたすため，ドレナージやシャ ントの設定圧を高くする必要がある.

\section{5. もやもや病}

小児例ではほとんどの例が脳虚血で発症する，泣くこ とによって脳虚血が誘発されるため，年少児では周術期 に主に母親の付き添いを依頼することになる，幼児期以 降の例では distraction や preparation の手法を処置や検 査に試みる。術後は脳虚血のみならず，直接吻合の場合 は過灌流による神経症状の悪化に注意する ${ }^{11}$.

\section{6. 頭部外傷}

小児虐待による予後不良因子は重症頭部外傷の頻度が 高いので，小児では第三者によって目撃されていない家 庭内の外傷では常に虐待の可能性を念頭に置く。柔らか いベッドやソファに子どもを投げつければ，外表上明ら
かな外傷は発生しない. 聴取した病歴と実際の外傷の程 度に大きな差がある場合（つかまり立ちができない時期 の乳児に頭蓋骨骨折を認め，保護者は「3 歳の姉が投げ た哺乳瓶が赤ちゃんの頭に当たつた」などと訴える)，ネ グレクト（処置されていない強いおむつかぶれ，污れた ままの衣服，異常な瘦せなど）の疑いがあれば，疾患の 重症度にかかわらず，児を保護者からの分離，保護を目 的に直ちに入院させる。虐待の疑いで児童相談所に通報 し，その後の方針は担当医単独ではなく医療施設として 児童相談所と協議し, 軽症であっても家庭の安全性が確 認できるまでは入院を続ける。医療者は犯人探しではな く，患児の安全の維持と治療とに専念する.

年少児の胸を両手で抱えて前後に強く摇らすと，大き い頭部で頝部の筋肉が未発達なため，頝部が前後に大き くしなって頭部の前後への加速度運動が発生し, この結 果 shaken baby syndrome が発生しやすい. 強い加速度運 動で脳と頭蓋との間の位置のずれが生じ，脳表と矢状静 脈洞（硬膜）とをつなぐ橋静脈の損傷をきたして，大脳 半球間裂に硬膜下血腫が発生しやすい。 また，眼球も頭 部と同じような機序で網膜出血をきたすことがきわめて 多いため，虐待を疑えば網膜出血の有無を検索する，日 本では，つかまり立ちをしていて転倒し痤攣と急性硬膜 下血腫をきたす非虐待例が報告されている5 が，欧米で はこのような病態は虐待によるものとみなされ，意見が 分かれる。

\section{おわりに}

小児期の周術期管理は成人とはまったく異なるように みえる。確かに胎児期や新生児期から乳児期には他の年 齢層にはない知識が必要であるが，管理の原則は成人例 と同じである。より多くの若い脳神経外科医に小児脳神 経外科領域への興味をもってもらい，この領域を次世代 の脳神経外科医に託したい。

\section{文 献}

1) Fujimura M, Mugikura $S$, Kaneta $T$, Shimizu $H$, Tominaga $\mathrm{T}$ : Incidence and risk factors for symptomatic cerebral hyperperfusion after superficial temporal artery-middle cerebral artery anastomosis in patients with moyamoya disease. Surg Neurol 71:442-447, 2009.

2）小宮山雅樹：4 章 治療，§ 3. 血管内治療. 横田 晃 監, 山崎麻美, 坂本博昭編, 小児脳神経外科学. 京都, 金芳堂, 2009, pp.194-215.

3) Kulkarni AV, Drake JM, Kestle JR, Mallucci CL, Sgouros S, Constantini S; Canadian Pediatric Neurosurgery Study Group: Predicting who will benefit from endoscopic third ventriculostomy compared with shunt insertion in child- 
hood hydrocephalus using the ETV Success Score. J Neurosurg Pediatr 6:310-315, 2010. (Erratum in J Neurosurg Pediatr $7: 221,2011$.

4）松田一郎：小児医学倫理ノート和の思想との対話. 東 京, 日本評論社, 2004.

5）西本 博, 栗原 淳: 家庭内での軽微な外傷による乳児 急性硬膜下血腫の再評価. 小児の脳神経 31:215-223, 2006.
6) Sakamoto H, Kitano S: Reexpandability of the ventricular system of hydrocephalic children in the event of shunt occlusion. Childs Nerv Syst 22: 517-522, 2006.

7）坂本博昭：5 章 先天性疾患， $\S 3$. 二分脊椎， 2 . 脊髄 髄膜瘤。横田 晃監，山崎麻美，坂本博昭編，小児脳神 経外科学。京都，金芳堂，2009，pp.268-299.

8）山崎麻美：胎児期水頭症 診断と治療ガイドライン。改 訂 2 版，京都，金芳堂，2010.

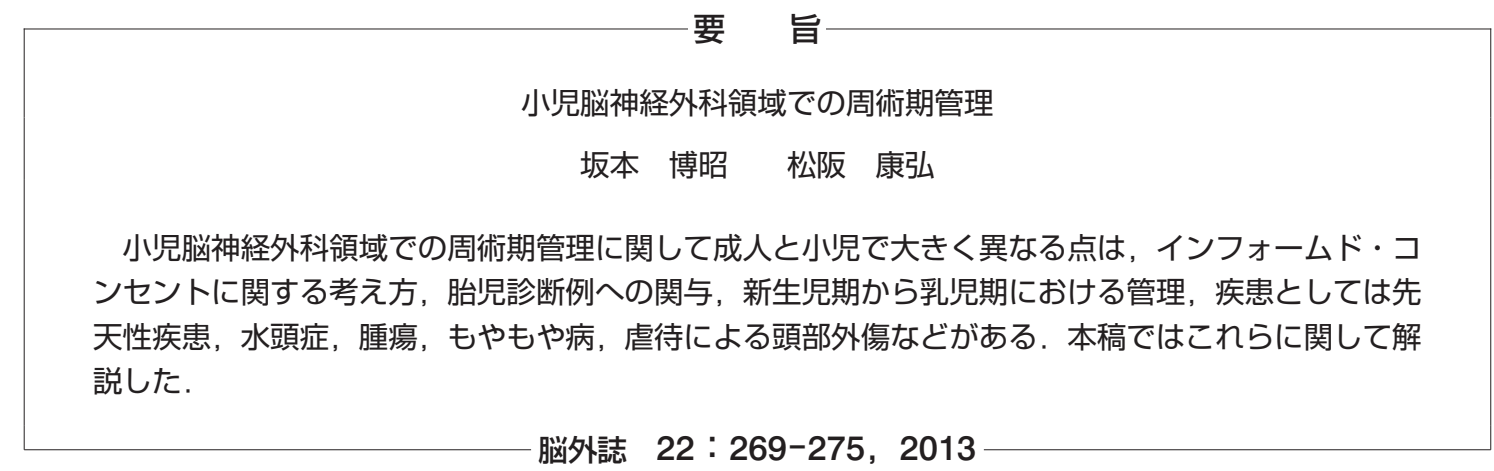

